\title{
Team Accelerated Instruction, Initials, and Problem-Solves Ability in Junior High School
}

\author{
1,2Sri Adi Widodo, ${ }^{2}$ Agustina Sri Purnami, ${ }^{3}$ Rully Charitas Indra Prahmana \\ ${ }_{1}^{1}$ Mathematics Education, Universitas Pendidikan Indonesia, Jl. Setiabudhi, Bandung \\ 2Mathematics Education, Universitas Sarjanawiyata Tamansiswa, Jl. Kusumanegara 157, Yogyakarta \\ 3Mathematics Education, Universitas Ahmad Dahlan, Jl. Pramuka, Kav. 5, Pandeyan, Yogyakarta \\ e-mail: sriadi@ustjogja.ac.id
}

\begin{abstract}
Abstrak
Penelitian ini bertujuan untuk menguji keefektifan Team Accelerated Instruction (TAI) terhadap kemampuan memecahkan masalah matematika siswa ditinjau dari kemampuan awal siswa. Penelitian ini adalah eksperimen dengan 367 siswa sebagai sampel penelitian yang diambil dengan menggunakan teknik cluster. Variabel penelitian ini adalah kemampuan memecahkan masalah, kemampuan awal, dan model pembelajaran. Analisis data yang digunakan adalah analisis varians. Berdasarkan hasil analisis data, dapat disimpulkan bahwa (1) TAI lebih efektif digunakan dibandingkan Direct Instruction (DI); (2) Siswa berkemampuan awal sedang lebih baik jika dibanding dengan siswa berkemampuan awal rendah dan tinggi; (3) Pada siswa berkemampuan awal sedang, pembelajaran TAI lebih efektif digunakan jika dibandingkan dengan pembelajaran langsung; dan (4) Pada TAI dan DI, kemampuan memecahkan masalah matematika relatif sama.
\end{abstract}

Kata Kunci: Team Accelerated Instruction, Direct Instruction, Kemampuan awal, Kemampuan memecahkan masalah.

\begin{abstract}
This research aims to test the effectiveness of the Team Accelerated Instruction (TAI) towards the ability of the students to solve mathematics problems based on their initial ability. This study is an experiment with 367 students involved as the research sample taken using the cluster technique. The research variable is the problem-solving ability, the initial ability, and the learning model. Analysis of variance was used to analyze the data which leads to the conclusions that (1) the TAI is more effective than the Direct Instruction (DI); (2) the students having moderate initial ability performed better compared to the lower and the higher initial ability; (3) among the students with moderate initial ability, TAI was more effective to be used than DI; and (4) in the implementation of TAI and DI, the problem solving ability of the students is relatively similar.
\end{abstract}

Keyword: Team Accelerated Instruction, Direct Instruction, Initial ability, Problem-solving ability.

How to Cite: Widodo, S.A., Purnami, A.S., \& Prahmana, R.C.I. (2017). Team Accelerated Instruction, Initials, and Problem-solves Ability in Junior High School. International Journal on Emerging Mathematics Education, 2(1), 193-204. http://dx.doi.org/10.12928/ijeme.v1i2.6683

\section{INTRODUCTION}

Each student has different learning experiences during the learning process. It is the initial capital for the students to join the further learning activities. This experience dramatically influences the interest of learning and becomes the basis for accepting new experiences that will significantly assist in student learning interests. The students' description of the readiness to receive further materials is called initial abilities (Anggraini et al., 2013; Nurhasanah et al., 2017). Initial ability is a skill which the students possess at the beginning of the learning. In other words, the initial ability is a prerequisite that must be mastered by students before joining a learning activity. 
The mathematics material is hierarchically arranged abstract concept and deductive reasoning. Thus, the mathematics material or concepts at the previous level are closely related to the understanding of mathematical concepts at the next level (Hudoyo, 1990). Regarding the concept of the tangent of circles, students should at least master the material about (1) basic arithmetic operations such as addition, subtraction, division, and multiplication, (2) square, (3) circular circumference, and (4) Pythagorean theorem.

In mathematics learning, problems are usually in the form of mathematics tasks addressed to the students. A problem could be a mathematical problem for a student if the student has no experience to solve it, but the student is willing to solve it (Hudoyo, 1990). A task is called a problem depending on the knowledge to answer. A task is not a problem for someone who can answer it by using routine procedures, but it becomes a problem for those who require the organization of their existing knowledge and be challenged to answer.

The task of $1234 \times 5$, in general, can not be categorized as a problem for junior high school students because they have learned the procedure to solve the problem at the previous level. Meanwhile, the task of "Prove that $a^{9}-a$ is divisible by 6 , for every integer $a$ " will be a problem or not depending on each who face it. For student $A$, a task can be a problem because the student $A$ has not been experienced to solve it. On the contrary, student B who has ever solved the task previously will not consider the task as a problem, although student $A$ and student $B$ are in the same condition and time.

Problem-solving is an accelerated skill that must be mastered by students (Pardimin \& Widodo, 2016). There are several reasons that problem-solving becomes essential and becomes one of the necessary skills of a person in solving mathematics problems. First, if the students are trained to solve the problem, they will be able to make decisions, because they have become skilled about how to collect relevant information, to analyze information, and to realize the need to re-examine the results that have been obtained (Widjayanti, 2009). Second, problem-solving can be used to formulate concepts, develop ideas they have, and capital success for students in solving mathematical problems, because a concept or principle will be meaningful if it can be applied in problem-solving (Widodo, 2013). Third, the mathematical standards in schools should include standard content and process standards. Process standards include problem-solving, reasoning and verification, linkage, communication, and representation (NCTM, 2000). Fourth, one of the objectives of mathematics learning in Indonesia is that students are expected to foster critical thinking skills, logical, systematic, thorough, effective and efficient in solving problems (BSNP, 2006).

In mathematics learning, students are expected to be able to solve problems that include the ability to understand problems, design mathematical models, complete models, and interpret the solutions obtained (Windari et al., 2014). With problemsolving, mathematics does not lose meaning because a concept or principle will be meaningful if it can be applied in problem-solving.

Steps to solve mathematical problems are understanding the problem, making plans, implementing plans, and re-examining answers (Polya, 1973). Dominowski (2002) states there are three general steps to solving a problem, namely: interpretation, production, and evaluation (Widjajanti, 2009). Bransford states that the steps to solve the problem are (1) problem identification, (2) define the problem through the process of thinking about the problem as well as segregate relevant information, (3) exploration of solutions through alternative search, brainstorming, and checking various perspectives, (4) implementing alternative strategies selected, 
and (5) reviewing and evaluating the consequences of the activities undertaken (Purnomo and Mawarsari, 2014). Furthermore, Wickelgren proposed problem-solving steps that are analyzing and understanding a problem, designing and planning a solution, exploring the solution to a difficult problem, verifying a solution (Lidnillah, 2014).

Based on the problem-solving step, the principle of problem-solving steps refers to the stages of Polya (Suryana, 2015; Lidnillah, 2014). At the problem-solving step of Bransford, the phase of problem identification and defining the problem is regarded as one step in the problem understanding of Polya. In the exploration of solutions through alternative searching, brainstorming and checking from different perspectives is a plan to solve the problem, implementing the chosen strategy alternatives is the step of implementing the plan, and the fifth step in Bransford step is the fourth step in solving the Polya problem. Solving problems from Dominowski, for the first stage of interpretation is a step to understanding the problem Polya, the production phase is the merging of two stages Polya that is planning and executing the plan to solve the problem. Similarly, in the last step Dominowski, the evaluation is a step to re-examine the answer from Polya.

Based on the review, it can be concluded that the problem-solving ability is an activity to find the solution of the mathematical problems encountered by using all the knowledge possessed. In general, the problem-solving steps lead to the problemsolving steps of Polya, that is understanding the problem, making plans, implementing the plan, and re-examining the answers. So the ability to solve mathematical problems will later use problem-solving from Polya.

To improve student learning outcomes, one can use varied learning (Heden, 2003; Rahin, 2009). In general, the effectiveness of students in the academic field can use Group Investigation for history or geography lessons while for math lessons can use Team Accelerated Instruction (Robinson, 1991). Team Accelerated Instruction was used to study mathematics in grade 3 - 6 students (Slavin \& Lake, 2008), but did not rule out use in higher classes (Hall, 2007).

In the Team Accelerated Instruction, team members can learn about different materials. Members of one group help each other, work together to answer the problem on the answer sheet and discuss it if there is a problem. The final test is done individually, students are not allowed to help each other, and the value that has been obtained is noticed by the students. Every week, teachers pay attention to the many materials that have been completed by all team members and reward the teams that achieve the highest score (Slavin, 1992).

Teachers also have an important role in the learning system, especially in improving the quality of learning. To attract student learning, the teacher must use the learning model besides the learning model of language learning. Learning using Direct Instruction model can cause the students to feel bored. This is because the Direct Instruction model of communication patterns run in one direction so that learners feel not directly involved in learning.

Based on the problem, the purposes of this research are (1) to know the effective learning model used in learning mathematics, (2) to know the ability to solve the problem better at each level of initial ability, (3) the effectiveness of the learning model used, (4) to determine the level of initial ability of students who have the ability to solve better mathematics problems in the learning model of Team Accelerated Instruction, and (4) to know the level of initial ability of students who can solve mathematics problems better in the Direct Instruction. 


\section{RESEARCH METHOD}

This research was a quasi-experimental research. This research intended to give treatment to the sample, then the researcher wanted to know the effectiveness of each treatment. The treatment is the use of Direct Instruction and the Team Accelerated Instruction.

The population in this research is all students of class VIII SMP in Yogyakarta, as many as 57 schools. The sampling technique used cluster random sampling technique. The sampling steps with cluster random sampling technique are (1) population divided by school, (2) school group was randomized using lottery so that obtained by six schools used as research setting, (3) the six schools that have been taken by lottery randomized again based on Classes owned by each school, it aims to obtain two classes that are used as research samples. By using this sampling technique obtained 6 six schools with two classes in each school. The classes and schools used as research sites are (1) class VIII D and VIII B at SMP N 4 Yogyakarta, (2) class VIII B and class VIII C at SMP N 10 Yogyakarta, (3) class VIII A and Class VIII B at SMP N 11 Yogyakarta, (4) class VIII SMP N 13 Yogyakarta, (5) class VIII-E and VIII A at SMP Muh 5 Yogyakarta, and (6) class VIII C and VIII A at SMP Muh 7 Yogyakarta.

In this research, there is one dependent variable and two independent variables. The ability to solve mathematical problems becomes the dependent variable while the learning model and initial ability become independent variables. The ability to solve mathematical problems is an ability possessed by learners to solve mathematical problems encountered by using all the mathematical knowledge possessed by learners. The learning model is the way used to convey the subject matter to the students. The learning model used is the Team Accelerated Instruction given to the experimental group and the Direct Instruction given to the control group. Initial abilities are the abilities students possess before obtaining material about the tangent of the circle. Furthermore, students' initial ability is categorized into three categories, namely high, medium and low. The guidance used is score $>\bar{X}+0,5 S D$ with the high category, $\bar{X}-0,5 S D \leq$ score $\leq \bar{X}+0,5 S D$ with the medium category, and score < $\bar{X}-0,5 S D$ with low category.

The test method is used to collect data of initial ability data and the ability to solve mathematical problems on the subject of the circle. Mathematical Problem Solving Tests (TPMM) aims to derive data related to a student's ability score to solve mathematical problems on the subject of the circle. While the initial ability test aims to obtain data related to the value of the ability to solve students' math problems associated with the subject of the circle. TPMM is designed in the form of a description problem that refers to (1) the length of the tangent line, (2) the distance of two circles, and (3) the wake area formed from the tangent line. The test of initial capability is in the form of multiple choice with four answer options and refers to the material that influences in studying the tangent of the circle. The material that affects or the prerequisite material in studying the tangent of the circle includes the basic arithmetic, power and root operations, circumference of the circle, and Pythagoras theorem.

The initial test of ability and the mathematical problem-solving tests used have been tested previously. The purpose of the initial capability test instrument and the problem-solving test is first tested is to obtain a good instrument. Budiyono (2015) states that before the tests are used, it is needed to be tested in advance to see (1) whether the instrument has fulfilled the validity requirements or not, and (2) from the 
point of the instrument must be seen whether the item has fulfilled the feasibility or not. Based on the test results of initial ability test obtained 40 questions that qualify with the reliability index of 0.918 , while the problem-solving test obtained 3 questions that meet the requirements of reliability index of 0.70 .

To test the proposed hypothesis, two-way ANOVA was followed by the Schefe test. The proposed hypothesis is that (1) Team Accelerated Instruction is more effective when compared with direct instruction, (2) Students with high initial ability has the ability to solve math problem better than middle and low ability students, (3) Among students with medium ability, the Team Accelerated Instruction is more effective when compared with the Direct Instruction, (4) in the Team Accelerated Instruction, students with medium initial ability have better problem-solving abilities than high and low ability, and (5) in the Direct Instruction, Students with high initial ability have better problem-solving skills when compared with medium and low ability.

\section{RESULTS AND DISCUSSION}

At the end of the learning, students are given a problem-solving test and then performed two-way ANOVA. This test is performed after the prerequisite test Anava fulfilled. The ANOVA prerequisites test are (1) the samples taken from normally distributed populations and (2) the variance of some normally distributed populations (Budiyono, 2004).

The normality test is used to determine whether the sample is from a normally distributed population. Normality test used in this study is the Lilliefors Test. Normality tests were performed on the data of students' experimental mathematics problems, control groups, high initial ability students, moderate ability students, and low-skilled students. The calculation result obtained that $\mathrm{L}_{\max }$ value less than $\mathrm{L}_{\text {tabel }}$ with $5 \%$ significance level (see Table 1). So it can be concluded that the samples taken are from the normally distributed population.

Table 1. The Normality Test

\begin{tabular}{lccl}
\hline \multicolumn{1}{c}{ Normality Test } & L $_{\max }$ & Ltabel & Concluded \\
\hline Experiment Group & 0.063 & 0.067 & The normally distributed \\
Control Group & 0.057 & 0.064 & The normally distributed \\
High-Ability Students & 0.069 & 0.073 & The normally distributed \\
Early Moderate Students & 0.069 & 0.072 & The normally distributed \\
Low-Skilled Students & 0.102 & 0.105 & The normally distributed \\
\hline
\end{tabular}

Homogeneity test aims to determine whether the variances of some populations are equal or not. In this research homogeneity test of variance used is Barlett test. The homogeneity test of variance was done to data of problem-solving ability of mathematics based on the group of learning model and data of problem-solving ability of math based on the group of a level of student's initial ability. After the calculation of

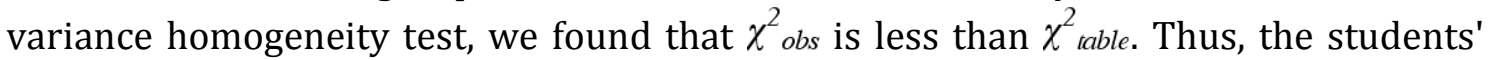
ability in solving mathematical problems based on the learning model and initial skill level have the same variance (see Table 2).

Table 2. The Homogeneity Test

\begin{tabular}{cccc}
\hline Homogeneity Test based on & $\chi_{\text {obs }}^{2}$ & $\chi_{\text {table }}^{2}$ & Concluded \\
\hline Team accelerated instruction, initials, and problem-solves ability in junior high school \\
Widodo, Purnami, \& Prahmana
\end{tabular}




\begin{tabular}{cccc} 
Learning Model & 0.675 & 3.841 & Homogeneity of Variance \\
Initial Skill Level & 3.267 & 5.991 & Homogeneity of Variance \\
\hline
\end{tabular}

The calculation of two-way ANOVA is presented in Table 3 and Table 4.

Table 3. Summary From Calculating Two-Way ANOVA

\begin{tabular}{lrcccc}
\hline \multicolumn{1}{c}{ From } & Sum of square & df & $\begin{array}{c}\text { Mean } \\
\text { square }\end{array}$ & Fobs $_{\text {om }}$ & F $_{\text {tabel }}$ \\
\hline Learning Model & 335,550 & 1 & 335,55 & 12,46 & 3,84 \\
Initial Skill Level & 189,853 & 2 & 94,93 & 3,52 & 3,00 \\
Interaction & 11,136 & 2 & 5,57 & 0,21 & 3,00 \\
Galat & 9776,879 & 363 & 26,93 & - & - \\
Total & 10112,429 & 368 & - & - & - \\
\hline
\end{tabular}

From Table 3, it can be concluded that (1) there is a difference in the ability to solve mathematical problems between the students learn by using the Team Accelerated Instruction and the students learn by using the Direct Instruction, (2) each level of initial ability has the ability to solve different mathematical problems, and (3) there is no interaction between the learning model and initial ability towards the problem-solving ability.

Table 4. Average and Marginal Rate

$\begin{array}{ccccc}\text { Lowitial } & & & & \\ \text { Learning } \\ \text { Model }\end{array}$

\section{First Hypothesis}

Based on the Two-Way ANOVA, we got $\mathrm{F}_{\text {obs }}=12.46$ and $\mathrm{F}_{\text {tab }}$ of 3.84. Thus, $\mathrm{F}_{\mathrm{obs}}>$

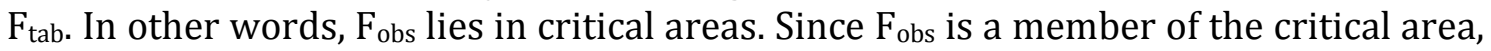
$\mathrm{H}_{0 \mathrm{~A}}$ is rejected, this means that there is a difference in the ability to solve mathematical problems between students treated with the Team Accelerated Instruction and the students treated with the Direct Instruction. Based on the marginal rate of students treated with Team Accelerated Instruction is 21.63 whereas in the students treated by a direct instruction is 19.50 so it can be concluded that the ability to solve mathematical problems in students using Team Accelerated Instruction is better when compared with the students who use direct instruction.

In the Team Accelerated Instruction, there is a high-priority student to become a peer tutor within the group to assist students with initial abilities. With individual guidance within the group, the low and moderate advanced students will get assistance during learning. So, the ability of students in studying the tangent of circle become increasing. In contrast to the Direct Instruction, in this model the students are more likely to be passive, the teacher is difficult to control the learning outcomes of each student, and this learning model is boring for the students. As a result, students 
become reluctant to learn mathematics materials. As a result of the ability of students in solving mathematics problems to be less. This is why the general learning model of Team Accelerated Instruction has resulted in the ability to solve mathematical problems better than Direct Instruction on the circle tangent.

A lesson is said to be effective when it meets the primary requirements of effectiveness, i.e. (1) high student learning time presentation devoted to teaching and learning activities, (2) average behavior of high performing tasks among students, (3) provision of teaching content and ability Students take precedence, and (4) develop a familiar and positive learning atmosphere (Triyanto, 2009: 20). To measure the effectiveness of learning can be done by providing tests to learners. This is because the test can be used to evaluate various aspects of teaching.

A measurement of the effectiveness of learning should always be associated with the achievement of learning objectives. One indicator that can be used to define the effectiveness of learning is the carefulness of behavioral mastery. The learned mastery of learned behavior often referred to as the performance error rate, can be used as an indicator to define the effectiveness of learning (Reigeluth \& Merrill, 1979). The more accurately the students master the learned behavior, the more effective the lesson has been, the smaller the error rate, the more effective the lesson will be.

So the effectiveness of learning can be measured by giving a set of tests to learners. The test is used to measure the extent of the learners' skills or the mastery of the learner's material in understanding mathematics. Because one of the objects of this research is the ability of students in solving mathematics problems, the skills or competencies that must be possessed are students able to solve or solve mathematical problems faced by learners.

By looking at the marginal rate, it can be concluded that in mathematical problem-solving skills, Team Accelerated Instruction is more effective when compared with direct instruction.

\section{Second Hypothesis}

Based on the two-way ANOVA, it is obtained that $\mathrm{F}_{\mathrm{obs}}=3.52$ and $\mathrm{F}_{\mathrm{tab}}$ of 3.00. So $\mathrm{F}_{\text {obs }}>\mathrm{F}_{\mathrm{tab}}$, in other words, $\mathrm{F}_{\text {obs }}$ are in Critical Areas. Since $\mathrm{F}_{\text {obs }}$ is a member of the Critical Area $\mathrm{H}_{0 \mathrm{~B}}$ is rejected, this means that at each level of initial ability can solve different mathematical problems, in other words, if viewed based on the students' initial ability, the ability to solve mathematical problems was varied.

Furthermore, from the post hoc, it is found that the critical region lies in $\mathrm{F}_{\text {obs }}>$ 6.00 , but also the conclusion that (1) $F_{1 .-2}$. ( $\left.F_{\text {obs }}\right)$ of 1.464 , so $F_{\text {obs }}<6.00$ in other words $\mathrm{F}_{\text {obs }}$ are not in the critical area. This means that high and low initial students can solve relatively the same mathematical problems. (2) $F_{2 .}$ - 3. $\left(F_{\text {obs }}\right) 6,076$, so $F_{\text {obs }}>6.00$, in other words, $\mathrm{F}_{\mathrm{obs}}$ are in a critical area. This means that students with moderate and low initial ability have different mean ability to solve math problems. By looking at the marginal rate in the initial moderate skilled students of 21.17 and the low margin rate of the low-ability students of 19.32, it can be concluded that students with Two-Way ANOVA ability are better able to solve problems when compared with low-skilled

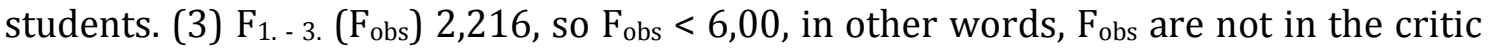
area. This means that high and low initial students can solve relatively similar mathematical problems. Based on this it can be concluded that students with an early ability are having the ability to solve better math problems when compared with low and high initial students.

Based on the observations made, high-ability students tend to underestimate the learning of mathematics in other words high-ability students feel that they have been

Team accelerated instruction, initials, and problem-solves ability in junior high school Widodo, Purnami, \& Prahmana 
able to solve math problems. This is because they already have a better initial ability when compared with early and low-grade students. However, high-ability students have a habit of solving math problems regardless of Polya's steps used as an assessment indicator. Most of the early high-ability students solve mathematical problems encountered by directly writing the third stage of Polya (the stage of implementing the plan). So, on the student answer sheet, there are only steps to solve the problem, and not write the stage of understanding the problem, plan to solve the problem and re-examine the answers that have been written.

This is in line with previous research that learners have a habit of mistakes in the form of learners do not write down what is known and what is asked of the problem it faces, learners have a tendency to solve problems by directly writing the steps at the stage of implementing the plan Or steps answered (Widodo, 2014; Widodo \& Sujadi, 2015; Widodo, 2017). This is what causes the problem-solving ability score to be less than optimal.

The mathematical material is very much concerned with abstract ideas that are arranged in hierarchical and deductive reasoning (Hudoyo, 1990). So the material or ideas/concepts of mathematics at the previous level is closely related to the understanding of mathematical concepts at the next level. So learning mathematics brings consequences on the learning and learning process that requires more serious and deep thinking in learning mathematics.

If students have a low initial ability, learners have a problematic tendency in receiving the next material. This is because low-skilled learners do not have the prerequisite ability to study material related to the next material. This also affects the ability of learners in solving math problems. With low initial ability, learners have difficulty solving mathematical problems. This is because low-ability early learners do not have the prerequisite ability to solve mathematical problems given. This is what causes low-ability early learners can solve math problems has not been optimal.

Students with moderate proficiency are at least capable of sufficient prerequisite to receiving the next stage of mathematics. Regarding solving problems, new students have a meticulous tendency to solve math problems. Students with early skills in solving mathematical problems write down all stages of Polya namely the stage of understanding the problem, plan to solve the problem, implement the plan and look back at the answers that have been made. Even early-born learners are using the affirmation step at each end of the answer written on the answer sheet. This is what causes the score of students' ability to solve mathematical problems more optimally when compared with high and low initial students.

\section{Third Hypothesis}

Based on a two-way ANOVA test which has been done, it is found that $\mathrm{F}_{\text {obs }}=0,21$ and $F_{\text {tab }}$ equal to 3,00. So Fobs < Ftab in other words $F_{\text {obs }}$ is not in Critical Area. Since $\mathrm{F}_{\text {obs }}$ are not members of the Critical Area then $\mathrm{H}_{0 A B}$ is accepted, this means that there is no interaction between the learning model and the student's early ability to the student's ability to solve mathematical problems. In other words the difference in the ability to solve mathematical problems of students who obtain learning with different learning models consistent with each level of initial ability, as well as differences in the ability to solve mathematical problems for each level of consistent initial ability for each model of learning.

Based on the marginal rate, it is found that the average ability of students in solving mathematical problems using the Team Accelerated Instruction is better when compared with students using direct instruction for each level of initial capability. In

IJEME, Vol. 1, No. 2, September 2017, 193-204 
other words, the Team Accelerated Instruction generally generates more mathematical problem-solving skills when compared to direct learning models for both high and moderate or low initial students.

The effectiveness of learning is the learning process that achieves learning outcomes by established learning objectives (Kurniawan, 2012), to measure the effectiveness of learning of which can use the test (Reigeluth \& Merrill, 1979). Based on the result of the mathematics problem-solving test, it is found that in general, the average ability to solve the students' mathematical Accelerated with the Team Accelerated Instruction is better compared to the students using the direct instruction. So it can be concluded that the learning model of Team Accelerated Instruction, in general, is more effective when compared with using direct instruction. To know which learning model is the most effective use when viewed from the level of students' initial ability it must be seen the characteristics of students at each level of initial ability.

In the early high-ability students, learning using Team Accelerated Instruction resulted in better mathematical problem-solving skills compared to direct instruction, as well as low and moderate early-skilled students. This suggests that the learning model of Team Accelerated Instruction is more effectively used in mathematics learning. When viewed in each learning model used, the students with early skills in the Team Accelerated Instruction have better problem-solving skills when compared with the low and medium-skilled students, and the high-priority students on the direct learning model Have better problem-solving ability when compared with the low and medium-skilled students.

In general, high-ability students have a better understanding of the concepts relating to the mathematical material then better than the students with moderate and high initial skills. So that student with high initial ability in direct learning models has better problem-solving skills when compared with other initial skills. While in the learning model of Team Accelerated Instruction the ability to solve mathematical problems has not obtained optimal results when compared with other initial capabilities. This is because high-ability students tend to solve mathematical problems by directly responding in the third stage (the stage of implementing the plan).

Based on the above explanation, the learning model of Team Accelerated Instruction has not been effectively used in high initial students, although the average problem-solving ability among the high-ability students for the Team Accelerated Instruction is better than the direct instruction.

In general, low-skilled students do not have sufficient understanding of the concept to learn the next material. So that low-ability students can solve math problems that are less good when compared with students with moderate and high ability. Based on the cell average at low initial Accelerated, it was found that the ability to solve math problems both using the learning model of Team Accelerated Instruction and the direct instruction is still under the high and middle initial students. Based on that, then, the use of learning Accelerated Team Accelerated Instruction has not been effectively used in low-skilled students early. This is because the learning model of Team Accelerated Instruction directly resulted in problem-solving skills that have not been good for high-priority students of medium and high, although the average problem-solving ability among low-ability students for the Team Accelerated Instruction is better than the direct instruction.

Whereas in early moderate students, it was found that problem-solving ability with Team Accelerated Instruction was better when compared with direct instruction. 
When compared with other early-ability students on the use of Team Accelerated Instruction, early-skilled students were able to have better problem-solving skills when compared to high- and low-ability students. However, in the immediate learning model, early-skilled students are capable of solving problems in the midst of a highability, low-skilled student. Thus, in the early students, the use of Team Accelerated Instruction is more effective when compared with using direct instruction. This is because, in the early moderate students, the use of Team Accelerated Instruction results in better learning presentation when compared with using direct instruction. Based on this, it can be concluded that in the early-moderate students, Team Accelerated Instruction is more effective when compared with direct instruction.

\section{Fourth and Fifth Hypotheses}

To test the fourth and the fifth hypotheses, it is necessary to see first whether $\mathrm{H}_{0 A B}$ is accepted or not. In the ANOVA test obtained that the value of $\mathrm{F}_{\mathrm{AB}}$ observation of 0.21 while $\mathrm{F}_{\mathrm{tab}}$ of 3.00 so it can be concluded that there is no interaction between learning models and a different initial ability of the ability to solve mathematical problems, in other words, $\mathrm{H}_{0 \mathrm{AB}}$ accepted. Because $\mathrm{H}_{0 \mathrm{AB}}$ is accepted then post ANOVA test is not necessary. This is because the Accelerated to solve better mathematical problems of each cell of the same initial ability in the Team Accelerated Instruction and direct instruction can be seen from the marginal rate. Based on this, it can be concluded that in general on the direct instruction and Team Accelerated Instruction, the ability to solve mathematical problems in low-skilled students is as good as those with moderate and high priority students.

Based on the cell mean that in the learning model of Team Accelerated Instruction, students with initial ability can solve mathematics problem better than the low and high initial students. This can be seen in the cell for the Team Accelerated Instruction, where the high initial skilled student has an average of 21.57 , the initial skilled student has an average of 22.38 and the low initial student has an average of 20.16.

Seeing the average result of problem-solving ability among cells on direct learning model is obtained that the average ability to solve mathematics problems of low initial ability students is 18.64 , the average ability to solve the problem of students moderate initial ability is 20.16 and the average ability to solve the problem of high initial ability students is 19.21 . So it can be concluded that the ability to solve math problems of students with an early ability is better than low and high initial students.

The average of the initial skilled students is more if compared with the low and high initial students because the high-ability students do not solve the math problem with the steps to solve the problem from Polya so that the ability to solve mathematics problem is not optimal yet. While in low initial students because the student does not have enough prerequisite ability to learn mathematics on the subject of a tangent circle so that students with a low initial ability to get the score of problem-solving ability is not optimal. In contrast to moderately advanced students who have sufficient prerequisite skills and solve mathematical problems with Polya steps, the Team Accelerated Instruction to solve mathematical problems is better when compared with high and low initial students.

\section{CONCLUSION}

Based on the two-way ANOVA test, it was found that first, Team Accelerated Instruction is more effective when compared with Direct Instruction. Second, the students with moderate initial ability can solve the mathematical problem better when

IJEME, Vol. 1, No. 2, September 2017, 193-204 
compared to the students with the low and high initial ability. Third, among the students with moderate initial ability, the Team Accelerated Instruction is more effective rather than the direct instruction. Forth, both in the Team Accelerated Instruction and in the Direct Instruction, the problem-solving ability of the students is relatively equal.

\section{REFERENCES}

Anggraini, V.D., Mukhadis, A., \& Muladi. (2013). Problem based learning, motivasi belajar, kemampuan awal, dan hasil belajar siswa SMK. Jurnal Ilmu Pendidikan, 19(2), 187-195.

BSNP. (2006). Lampiran Peraturan Menteri Pendidikan Nasional No 22 Tahun 2006. Jakarta: Depdiknas.

Budiyono. (2004). Statistika untuk penelitian. Solo: UNS Press.

Budiyono. (2015). Pengantar penilaian hasil belajar. Solo: UNS Press.

Dominowski, R.L. (2002). Teaching undergraduates. New Jersey: Lawrence Erlbaum Associates Publishers.

Hall, C. (2007). Case study 2: An evidence-based practice review report, a systematic review of the effectiveness of cooperative learning approaches in improving the mathematics achievement of students in mainstream secondary schools. UCL Doctorate in Educational \& Child Psychology.

Heden, T. (2003). The reverse jigsaw: A process of cooperative learning and discussion. Teaching Sociology, 31(3), 325-332.

Hudoyo, H. (1990). Teori belajar untuk pengajaran matematika. Jakarta: Depdikbud.

Kurniawan, H. (2012). Upaya peningkatan efektivitas pembelajaran matematika melalui model pembelajaran kooperatif tipe Team Assisted Individualization (TAI) pada siswa kelas V SD Negeri Sidomulyo tahun pelajaran 2011/2012. Prosiding Seminar Nasional Matematika dan Pendidikan Matematika UNY, pp. 370-376.

Lidinillah, D.A.M. (2014). Heuristik Dalam Pemecahan Masalah Matematika Dan Pembelajarannya Di Sekolah Dasar. Bandung: UPI.

NCTM. (2000). Principles and standards for school mathematics. Virginia: NCTM.

Nurhasanah, F., Kusumah, Y.S., \& Sabandar, J. (2017). Concept of triangle: Examples of mathematical abstraction in two different contexts. International Journal on Emerging Mathematics Education, 1(1), 53-70.

Pardimin, \& Widodo, S.A. (2016). Increasing skills of student in junior high school to problem solving in geometry with guided. Journal of Education and Learning, 10(4), 390-395.

Polya, G. (1973). How to solve it: A new aspect of mathematical method. New Jersey: Princeton University Press.

Purnomo, E.A., \& Mawarsari, V.D. (2014). Peningkatan kemampuan pemecahan masalah melalui model pembelajaran ideal problem solving berbasis project based learning. Jurnal Kajian Pendidikan Matematika, 1(1), 24-31. 
Rahin, U. (2009). Metode bervariasi dapat meningkatkan prestasi belajar matematika siswa Kelas V SD Negeri I Olo-Oloho Kecamatan Pakue Kabupaten Kolaka Utara. Majalah Ilmiah Pendidikan Matematika dan IPA, 8(1), 18-27.

Reigeluth \& Merrill. (1979). Classes of instructional variables. Educational Technology, 19(3), 5-24.

Robinson, A. (1991). Cooperative learning and the academically talented student. Washington, DC: The National Research Center on the Gifted and Talented (NRCG/T-9106).

Slavin, R.E. (1992). Success for all: A relentless approach to prevention and early intervention in elementary schools. ERS Monograph.

Slavin, R.E., \& Lake, C. (2008). Effective programs in elementary mathematics: A bestevidence synthesis. Review of Educational Research, 78(3), 427-515.

Suryana. (2015). Penerapan pendekatan pemecahan masalah melalui soal cerita pecahan untuk meningkatkan hasil belajar siswa kelas IV SD $\mathrm{N}$ Ciherang Kecamatan Pamulihan Kabupaten Sumedang. Jurnal Cakrawala Pendas, 1(2), 1218.

Triyanto. (2009). Mendesain model pembelajaran inovatif dan progresif. Jakarta: Kencana.

Widjajanti, D.B. (2009). Kemampuan pemecahan masalah matematis mahasiswa calon guru matematika: Apa dan bagaimana mengembangkannya. Prosiding Seminar Nasional Matematika dan Pendidikan Matematika FMIPA UNY, pp: 402-413.

Widodo, S.A. (2013). Analisis kesalahan dalam pemecahan masalah divergensi tipe membuktikan pada mahasiswa matematika. Jurnal Pendidikan dan Pengajaran, 46(2), 106-113.

Widodo, S.A. (2014). Error analysis of guardians student in understanding the problem of divergence. In Proceeding of International Conference on Research, Implementation and Education of Mathematics and Sciences 2014 (pp. 467-472). Yogyakarta: Universitas Negeri Yogyakarta.

Widodo, S.A. (2017). Development of teaching materials algebraic equation to improve problem solving. Infinity, 6(1), 61-70.

Widodo, S.A., \& Sujadi, A.A. (2015). Analisis kesalahan mahasiswa dalam memecahkan masalah trigonometri. Jurnal Sosiohumaniora, 1(1), 51-63.

Windari, F., Dwina, F., \& Suherman. (2014). Meningkatkan kemampuan pemecahan masalah matematika siswa Kelas VIII SMP N 8 Padang tahun pelajaran 2013/2014 dengan menggunakan strategi pembelajaran inkuiri. Jurnal Pendidikan Matematika, 3(2), 25-28. 